\title{
The Media on the Subject of Media Literacy in the Croatian Education System
}

Preliminary communication _ DOI 10.22522/cmr20170226 _ received on 28 July 2017

UDK 316.774:316.773.3 - 003.02:37.014(497.5)

\section{Danijel Labaš}

University Department of Croatian Studies, University of Zagreb, Croatia. Email: dlabas@hrstud.hr (corresponding author)

\section{Petra Marinčić}

Television Zapad, Croatia. Email: petra.marincic@zapad.tv

\section{Abstract}

Media literacy, which has been rapidly developing in many European countries during the past decades, is still at its beginning in Croatia. It remains excluded from the formal education programmes. Meanwhile, there are various informal types of media education dedicated to information and media literacy, usually thanks to the efforts of non-governmental organisations (Labaš, 2015). What kind of impact did Croatian Internet news portals have on media literacy, and what is their position on it and its place in the education system during the debate about the curricular reform, and were they encouraging debate with the interested public in this period? This paper aims to answer these questions by investigating the news portals writings (Večernji list, Jutarnji list, Slobodna Dalmacija, Novi list, Glas Slavonije and 24 sata) in the time period between 1 January and 1 July 2016.

Keywords: media, education, media and information literacy, Croatian education system 


\section{Introduction}

Media education that has been developing for decades in many European countries is still at its beginning in Croatia, and it still has not been included in the programmes of regular formal education in a satisfactory manner. At the same time, there are different informal kinds of media education and incentives for information and media literacy initiated by civil associations (Labaš, 2015). Acquiring media literacy and equal participation in media education of children and young adults is supported by the fact that teachers use media in the classroom because it improves the quality of teaching, encourages creativity with children and teenagers, as well as critical thinking (Ciboci, Osmančević, 2015). Out of 49 teachers who took part in research by Lana Ciboci and Leali Osmančević on media literacy, almost half of the respondents said that they did not have enough knowledge on media to teach about it and thought that media culture should not be part of the Croatian language classes. According to the National framework curriculum, media culture is taught as part of several subjects, which indicates that media education has not been recognized enough in Croatian schools. Neither is the cooperation between ministries adequate, nor is there an official body or council to deal with the field of media literacy (Car, Kanižaj, Kralj, 2014). Teachers find themselves not competent enough, yet $62 \%$ of the public have pointed out in 2013 that media education should be obligatory from a young age (Ipsos Puls, Association for Communication and Media Culture, 2013), and only two years later in 2015, 90\% of the respondents said that children and parents need to be constantly educated in the way media affects the development of children, while $60 \%$ have heard of the expression media literacy or media education (Communication Studies Department, University Department of Croatian Studies, 2015).

Taking into account the fact that a large number of children and young adults live with the media because $80 \%$ of households have Internet access (Communication Studies Department, University Department of Croatian Studies, 2015) and that media literacy is the most important literacy of the $21^{\text {st }}$ century, it is justified to ask oneself if there is enough awareness of the importance of media and media literacy, if media literacy in Croatia is in a crisis, and what steps are to be taken to change this. Media is at the service of citizens, it influences them, and depending on the content, has positive and negative effects. What 
kind of effects did media cause, which stand did news portals take during the discussion on curricular reform and did they initiate discussion with the public? This paper will answer these questions by providing results to research on posts on news portals in the period from 1 January to 30 June 2016.

The subject of this research is the articles published on news portals and the way they informed the public on education, curricular reform and especially on the significance of media literacy in education. The aim is to research if the media has contributed to the understanding of the importance of curricular reform through reporting on the topic or if it managed to deform reality and manipulate the public. For the objectives of this paper, the following daily news portals have been researched: Večernji list, Jutarnji list, Slobodna Dalmacija, Novi list, Glas Slavonije and 24 sata. The aim is to research the information value and quality of articles on media literacy and its meaning in the Croatian education system.

\section{The Role of Media, Public Interest and Media Literacy}

Due to today's “information flood” (Kunczik, 2014), emerging especially from the Internet, the question arises whether media serve the public interest and if the need for media literacy is being placed in the centre of the communication sciences, together with journalism and media ethics. While on the one hand we are all aware of the fundamental role of media to inform us, form us, entertain us and improve culture, but also the emerging problem of journalism that it is constantly being torn when deciding "upon criteria for the importance of a certain event for the public and the assumed interest of the recipient, and the possible positive or negative effect of reporting or not reporting" (Kunczik, 2014, p. 33), the state of media in Croatia depicts "the overwhelming sensationalism, low professional standards, and the advertisers set the trends and define the content through agencies in charge of placing propaganda in media" (Malović, 2014, p. 118), which do not contribute to the rights of the public and the public interest. Moreover, according to Stjepan Malović "Croatian media reality is spun into a thick yarn of primitive media ownership, professionalism is not being respected, not even recognized any more, journalists lose independence and become obvious manipulators or hide under the umbrella of auto-censorship, and it is no surprise 
that statistics on public opinion confirm that people are losing trust in journalism and media. International reviews are no better either” (Malović, 2014, p. 122).

Due to such a situation in the media, or one could say - due to the state of the opposite side, i.e. the recipients/the public - distrust and criticism against "increasingly present commercialization, trivialization and tabloidization of media content" is rapidly growing (Car, Matović, Turčilo, 2016, p. 1), which should raise awareness of the recipient and about the need for media education in education institutions during preschool, middle school and high school education, as well as lifelong learning. Viktorija Car, Lejla Turčilo i Marijana Matović (2015) said that media literacy was one of the prerequisites for media responsibility. However, global media literacy is being developed in different ways and different directions, and on the American continent - in Canada and the United States of America - it has been recognized and present since the 70 s of the $20^{\text {th }}$ century. In Europe, it is different. We could say that the pioneers are, among others, Len Mastermann from Great Britain, and among countries, Finland and Denmark, where media education entered the educational systems in 1970s. Ten years later, the same happened in Sweden and Germany (Maletić, 2014, pp. 142-143; Erjavec, Zgrabljić Rotar, 2000; Erjavec, 2005). In the Declaration on Media Education from 1982, UNESCO stresses the importance of introducing media education to all educational levels. Except for the concept of "media education", soon the concept of media literacy developed as well, extending to include users of different ages because today everyone needs to be literate in media (Zgrabljić Rotar, 2005, p. 6). UNESCO published the new "Declaration on Media and Information Literacy in the Digital Era" in 2014, in the preparation of which Croatian scientist Igor Kanižaj worked as well. "Starting from the assumption that, in today's world of media and media spectacles as alternative reality, it is no longer enough to be able to read and write to be literate, it is becoming clear that it is necessary to acquire knowledge on access and usage of media, and its technical, social, political and market functioning. It is also necessary to know that the media participates in creating our reality, which means also the symbolic languages it uses, and how to use it to accomplish more successful communication. This period is already a step ahead of media literacy”, says Nada Zgrabljić-Rotar (2005, p. 6), so the international community is demanding digital literacy, often written about by American scientist Renee Hobbs, which should enable citizens to learn about new media and new information and communication 
technologies which - whether we want to admit it or not - influence everyday life, work, health, leisure time, and finally education, but also the understanding of the educational system itself. "Since declaring independence in 1991, little has been done in Croatia to define and develop media education policies", although according to many studies, "children and young people in Croatia are significantly exposed to media every day”, as Igor Kanižaj and Viktorija Car warn us adding that "on the institutional level, in the Croatian education system, except for media culture, there is not a single official programme or lesson unit about media education", and therefore, claim that children and young adults in Croatia "within the existing education system have only partial access to media and media education (mostly through lessons on film culture and activities of the librarians) and only partially participate in creating media content (through school papers and magazines, school radio stations and journalism clubs)" (Kanižaj, Car, 2015, p. 23). Therefore, the subject of this research - in the frame of the integrated curricular reform that should include changes in the field of media literacy - seems even more urgent and relevant.

\section{Subject, Hypothesis and Research Objectives}

As already mentioned in the introductory part, if we take into consideration the fact that a great number of children and young adults unquestionably live with the media every day because $80 \%$ of households have Internet access (Communication Studies Department, University Department for Croatian Studies, 2015), and that media literacy is the most important literacy in the $21^{\text {st }}$ century, it is justified to ask oneself if there is enough awareness of the importance of media and media literacy, if media literacy in Croatia is in a crisis, and what steps are to be taken to change this. It was also pointed out that media are at the service of citizens, influences them, and, depending on the content, has positive and negative effects. What kind effects did media cause, which stand did news portals take during the discussion on curricular reform and did they initiate discussion with the public? This paper, by applying the content analysis method for the selected daily newspaper articles, will answer these questions by providing results on the research of posts on news portals in the period from 1 January to 30 June 2016.

The subject of this research is the articles published on news portals and the way they had 
been informing the public on education, curricular reform and especially on the significance of media literacy in education. The aim is to research whether the media has contributed to the understanding of the importance of curricular reform through reporting on the topic or if it has managed to deform the reality and manipulate the public. For the purpose of this paper, the following daily news portals were researched: Večernji list, Jutarnji list, Slobodna Dalmacija, Novi list, Glas Slavonije and 24 sata. The aim is to research information value and quality of articles on media literacy and its meaning in the Croatian educational system. The main hypothesis is that media have not paid enough attention to promoting media literacy in the Croatian education system. The specific objective is to study in which sections media literacy articles could be found, what the graphic elements of the articles look like, what the author's stand on the topic is, what the main sources of information are.

Other hypotheses are: 1 Articles superficially elaborated; 2 All articles graphically well depicted; 3 Sensationalist headlines dominate the articles; 4 Main topics the media reports on are the influence of politics on the implementation of the integrated curricular reform, protest, conflict between the Ministry and experts; 5 Main source of information is Boris Jokić, head of the Expert group for the implementation of the integrated curricular reform.

The basic unit of the content analysis was an article, and the analysis was split into five parts: 1) Characteristics of the article: day of publishing, type of article, section, author. 2) Graphics: elements, relation between the text and the graphics. 3) Headlines: characteristics of the headline - connection between the headline and the text, type of headline. 4) Subject of the article: topic, function, elaboration of the topic. 5) Information source: main source of information, number of listed sources, using unknown sources.

\subsection{The Results and Research Discussion}

By applying the content analysis method for the selected daily newspaper articles, 349 articles were analysed in 182 days, in the period from 1 January to 30 June 2016. The most articles were published in the newspaper 24 sata (95), and the least articles (28) were published in Glas Slavonije and Slobodna Dalmacija (Table 1). 
Table 1. Number of articles in online editions of daily newspapers

\begin{tabular}{|c|c|}
\hline Portal & f \\
\hline 24 sata & 95 \\
\hline Jutarnji list & 77 \\
\hline Večernji list & 75 \\
\hline Novi list & 46 \\
\hline Glas Slavonije & 28 \\
\hline Slobodna Dalmacija & 28 \\
\hline
\end{tabular}

According to the number of visits to online editions of daily newspapers, the most visited portal was $24 \mathrm{sata}$, which also had the most articles, while the distribution among other portals and published articles was almost completely identical (Table 2).

Table 2. Ranking of visits to daily newspaper portals (Source: https://www.similarweb.com/, 20 May 2017)

\begin{tabular}{|c|c|c|}
\hline Portal & World ranking & National ranking \\
\hline 24sata.hr & $\# 2476$ & $\# 7$ \\
\hline jutarnji.hr & \#2591 & $\# 8$ \\
\hline vecernji.hr & $\# 4352$ & $\# 11$ \\
\hline slobodnadalmacija.hr & \#7940 & $\# 19$ \\
\hline novilist.hr & \#24242 & \#57 \\
\hline glas-slavonije.hr & \#77941 & $\# 184$ \\
\hline
\end{tabular}

When authors of articles published on daily news portals write about media literacy, they do not use the expression "media literacy", but write about information and communication technology, respectively digital literacy. For example, Lidija Kralj in her article for 24 sata from 2 February describes 10 Reasons Why Educational Reform Should Not Be Stopped. The authors of articles do not recognize digital literacy when writing about interdisciplinary topics, with the emphasis on sustainable development, entrepreneurship, personal and 
social development, civil education and learning about learning ("learn how to learn" Večernji list, 14 January 2016). Večernji list was the only one to publish news on the round table held by the Association for Communication and Media Culture at Zagreb City Hall, and the author of the article said that "media literacy will not be a mandatory school subject" (19 January 2016). In the article from 30 May 2016, Večernji list lists ten skills employers favour most in employees, and some of them belong to the field of media literacy: 3 ability to communicate with people within and outside the organisation; 5 ability to collect and process information, 6 ability to analyse quantitative data, 7 technical knowledge related to workplace, 8 ability to use computer software, 9 ability to write and amend written reports.

Most articles were published on Wednesdays (24.9\%), followed by Tuesdays, Thursdays and Fridays (Table 3). Since the curricular reform was a topic which had been the subject of public discussion, it was surprising that the least number of articles were publish on Saturdays when people read daily newspaper and probably portals the most because the public has more free time available. Portals 24sata.hr and jutarnji.hr published the same number of articles on Wednesdays (26), next is Večernji with 13, Novi list with 10, Slobodna Dalmacija and Glas Slavonije with 6 articles. On Wednesday, 1 July, a demonstration 'Croatia can do it better' was organised as an act of support to the Expert group represented by Boris Jokić, as well as to the implementation of the reform, so it makes sense that most articles were published from Tuesday to Thursday. On Friday, most articles were published by Večernji and Jutarnji, and by Glas Slavonije on Saturday.

Table 3. Day of media publication

\begin{tabular}{|cc|}
\hline Day & $\%$ \\
\hline Monday & 16.3 \\
\hline Tuesday & 18.9 \\
\hline Wednesday & 24.9 \\
\hline Thursday & 16.9 \\
\hline Friday & 12.9 \\
\hline Saturday & 4.9 \\
\hline Sunday & 5.2 \\
\hline
\end{tabular}


Journalists wrote about the curricular reform, curricular documents, and public reactions using almost all journalist forms (Table 4). Novelty, truthfulness, topicality, importance and curiosity are important elements of news, and in a report, the journalist informs readers on the content of the event as if they had attended it themselves. Pieces of writing up to 10 to 15 rows were defined as articles, everything else a report. The most used journalist forms are reports, a high 53\% of them. Next are analyses where journalists wrote about the topic extensively, processed the causes and consequences of the curricular reform, and confronted opinions on the topic. The most analyses appeared in Jutarnji list, and the least in Slobodna Dalmacija. Also, this newspaper had the least news, which is the third most common form in daily newspapers. Altogether, there were $16.6 \%$ pieces of news, most of them in 24 sata. The most interviews, columns and comments were published in Jutarnji list.

Table 4. Article forms

\begin{tabular}{|c|c|}
\hline Form & $\%$ \\
\hline Report & 53.0 \\
\hline Analysis & 18.3 \\
\hline News & 16.6 \\
\hline Interview & 4.6 \\
\hline Column & 3.7 \\
\hline Commentary & 2.3 \\
\hline
\end{tabular}

The curricular reform was a topic that attracted a lot of public attention, so it appeared in many popular sections and online editions of daily newspapers (Table 5). This is supported by the fact that $68.8 \%$ of articles were published in the Croatia section, followed by the News section with $24.5 \%$ of the articles. In Novi list a couple of articles were published under the Rijeka section. A few sections were put into one category named Other, referring to all the articles in sections Jutarnji, Education, Culture, Analysis and Interviews. These are the sections in daily newspaper that are published on weekends, Saturday or Sunday. Most of the articles in the News section were found in 24 sata, and in Večernji and Jutarnji list, most articles were published in the Croatia section. 


\begin{tabular}{|c|c|}
\hline Section & $\%$ \\
\hline News & 24.5 \\
\hline Croatia & 68.8 \\
\hline Magazine & 0 \\
\hline Columns/Commentary & 3.0 \\
\hline Rijeka & 1.1 \\
\hline Other & 2.6 \\
\hline
\end{tabular}

Taking into account a different number of articles per online edition of daily newspaper and analysing the authors of articles, we found that the most articles were written by an author (54.2\%), followed by agency articles and editorial articles (Table 6). The most articles written by authors were published in Jutarnji list, and the least in Slobodna Dalmacija. The most editorial articles were published in 24 sata, and only one in Glas Slavonije. Večernji list and Novi list published the most agency articles, and Glas Slavonije the least. In some editions - such as editions of Večernji, Jutarnji and Novi listi - articles were published as a result of cooperation of authors, editorial offices and agencies, respectively writers and editorial offices or authors and agencies. As for articles by authors, they were written by daily newspaper journalists specialized in education, such as Mirela Lilek for Jutarnji, Marijana Cvrtila for Slobodna Dalmacija, and Irena Kustura for Večernji list.

Table 6. Authors of articles

\section{Author of article}

Author

Editorial office

Agency

Writer, editorial office, agency

Writer, editorial office

Writer, agency

\section{$\%$}

54.2

20.0

23.1

0.9

0.9

0.9 
Out of 349 articles, $98 \%$ had rich graphics, while only $2 \%$ of articles did not have any graphic elements. Articles did not have any tables or illustrations, although such elements would have made the reading easier, especially for financial data on the education budget, or the chronology of events. Framed texts were used in such articles.

In $91.4 \%$ of articles the text is larger than the photograph, while in $4 \%$ of articles, the text and the photograph are almost the same size. In $2.6 \%$ of articles the photograph is larger than the text, and in $2 \%$ of articles there is only text. In Večernji list and Novi list, there were no articles where the photograph was larger than the text, and in Novi list the text and the photographs were almost always the same size. In Večernji list and Slobodna Dalmacija, there were no articles that contain only text.

Authors of articles linked the headlines to the content in $94.9 \%$ of articles. In only 13 articles, i.e. 3.7\%, the headline is partially related to the content and such examples were found in 24 sata, Večernji list, and Glas Slavonije. Only a small percentage belongs to articles where it was not possible to determine the headline-content relation, and this occurred in 24 sata, Večernji and Jutarnji list. One article in Večernji list and Glas Slavonije did not have a headline.

Table 7. Headline-content relation

\section{Headline}

Related to content

Partially related

Impossible to determine

No headline
$\%$

94.9

3.7

0.9

0.5

Authors of articles (Table 8) attracted most readers with sensationalist headlines (38.4\%), a bit less with critical headlines (33.5 \%) and informative headlines (26.9\%). The most sensationalist headlines were found in 24 sata (25), and the least in Slobodna Dalmacija (10). The most critical headlines were found in 24 sata (29), and the least in Glas Slavonije (8). Next are informative headlines, with 24 sata (25) and Večernji list (21) being the most prevalent, while the least informative headlines were detected in Glas Slavonije and Novi 
list (11), and Slobodna Dalmacija (10 headlines). While analysing the content, we came across some headlines that we would like to list just as an illustration: First graders won't fear Fs anymore because there won't be any - sensationalist; After criticism, reading list changed - informative; MZOS: Integrated curricular reform continues according to plan informative, Education Committee agrees curricular reform is necessary, cannot agree when to start - critical, Teacher from Split made crowded Ban Jelačić Square cry, but Željka Markić was not impressed - sensationalist.

Table 8. Type of headlines

\section{Type of headlines}

Informative

Sensationalist

Critical

Cannot be determined

\section{$\%$}

26.9

38.4

33.5

1.2

Regarding availability of the information sources, using the information sources, and informing on details of the curricular reform, the media relied on Boris Jokić, Head of the Expert group. That way they approached the articles and certain topics very lightly and unilaterally, to be precise, $70.2 \%$ of the articles were approached that way, while $28.8 \%$ of them were elaborated in detail. Superficially and unilaterally handled articles can be distinguished on the basis of one information source used in $45.3 \%$ of the articles. The smallest difference between the in-depth and superficial articles was found in Glas Slavonije (15 superficial, 13 elaborated), while the biggest difference was found in 24 sata, which had also published the most articles on the curricular reform (10 in-depth, 95 superficial). Next was Slobodna Dalmacija with 7 in-depth and 21 superficial articles.

Authors of articles mostly used the function of informing the readers (Table 9) about the course of the curricular reform, its protagonists, issued curricular documents, their advantages and shortcomings, as well as the opposed opinions on its implementation. The function of informing the readers was the most dominant (43.3\%), followed by the function of promotion and criticism. Depending on the source of information, authors of articles 
were inclined to adjust the text to highlight the opinion of their source of information. In 24 sata, most of the articles used the function of promotion, followed by informing and finally criticizing. Večernji list published most articles with the purpose of informing readers, then to promoting the issue and criticizing. In Jutarnji list, the dominant function was informing, and the least dominant was criticizing. Glas Slavonije equally informed about the issue and promoted it in its articles, and most articles expressed criticism. Novi list published the most articles with the function to inform, then promote and finally criticize. The articles in Slobodna Dalmacija mostly used the function to promote the issue, followed by criticize and only then to inform.

Table 9. Function of articles

Function

Inform

Promote

Criticize

\section{$\%$}

43.3

29.5

27.2

While analysing the articles, we split topics into several categories (Table 10). Poor elaboration of articles using only one source of information is even more obvious due to topic choice. For example, the topics such as the situation in education, reasons why Croatia needs the curricular reform or its outcomes were less explored. This topic was addressed by Jutarnji list in most cases. There is a similar situation with the financial infrastructure necessary for the curricular reform implementation: this topic was mostly covered by Jutarnji list. Journalists mostly handled the issue of fees for the Expert group members for the curricular reform implementation. 24 sata wrote the most about the petition (supporting Boris Jokić and the Expert group members) and the demonstration on 1 June, and these topics were least covered by Glas Slavonije. The most common topic was the relationship between politics and the reform. In this context, it was mostly observed and analysed in what way the used sources of information politicized the dialogues between the public, experts and politicians, who showed support or hindered the curricular reform implementation. This topic became more prominent in May when Boris Jokić, dissatisfied with the support by the Ministry and minister Predrag Šustar, announced his resignation in the media. As 
for the curricular documents, they were mostly criticised by the sources of information, who gave statements in the media. The most criticised curricular documents referred to Croatian language classes (reading lists, omitted and new titles), History (not enough about the national history is taught in schools) and Biology (health education classes). Only $10.6 \%$ of articles pointed out the reform objectives in a positive way and explained why it was necessary for the Croatian education system. This topic was equally interesting to journalists of 24 sata, Jutarnji and Večernji list. Under Other, we put biographies of the information sources, for example of Predrag Šustar and Boris Jokić.

Table 10. Topics of articles

\section{Topics}

Objectives of the reform

Politics vs. reform

Curricular documents

Financial part

Situation in education

Petition/protest

Reactions, discussion

Other

\section{$\%$}

10.6

29.7

12.4

3.8

4.4

19.2

1.2

Authors of articles used only one source of information (45.3\%), which added to the superficiality of their articles and the issue of taking sides in the aspect of the curricular reform (Table 11). Out of 158 articles, this was most common in 24 sata (46), followed by Večernji (42), and Novi list (25). As for using three or more sources (27.5\%), this usually meant using three sources from the same side, supporting or criticizing a particular topic. In this context, there were 96 articles, 28 of them published in 24 sata, 24 in Jutarnji list, and 7 in Slobodna Dalmacija. Glas Slavonije stands out for not having published articles without a source, and 24 sata, Večernji and Novi list for not having articles without listed sources. The curricular reform was discussed by everyone: students, parents, teachers, scientists, academics, promoters of the initiative, politicians, union representatives, Ministry of Science, Education and Sport, 
working group experts for certain subjects and other. The media covered their statements from press conferences, visits in central information programmes of television stations such as HRT, Nova TV, RTL, N1 television. The most used statements by politicians were those by Željko Jovanović, Sabina Glasovac and Ladislav Ilčić. Experts available for releasing statements were Neven Budak, Ante Nazor and Ante Birin. Gordana Rusak, President of the Committee for Education, Science and Culture of the Croatian Parliament, who had made the decision to extend the expert working group to amend some of the curricular reform documents.

Table 11. Number of sources in articles

\section{Source}

Not listed

One source

Two sources

Three or more sources

No source

\section{$\%$}

1.2

45.3

15.2

27.5

10.8

According to the conducted analysis, when writing on the curricular reform, the media found themselves in quite a communication crisis. Since the information sources were not available on both sides equally, the media had to rely on Boris Jokić, while his main opponent - minister Predrag Šustar, was quiet and idle in the media (Table 12). However, the fact is that the media gave preference to Jokić and promoted his ideas, even supported the demonstration organised in support of the curricular reform implementation on 1 June. The demonstration was called 'Croatia can do better' according to Jokić's motto often used in media appearances. On the other hand, minister Šustar called the demonstration a "party". The dialogue between Boris Jokić and Predrag Šustar was inadequate and politicized, and in the media readers could only find out about the course of events on both sides, as shown in the following headlines: on one side - Ministry of Education: Curricular reform is above all groups and particular interests, and on the other, there is the headline: Jokić and his team resign due to political pressures. In the media, Šustar said: The job needs to be finished, errors corrected, and concluded: The reform is delayed, but will be continued, with Jokić or without 
him. In this case he showed aversion towards Boris Jokić, who had almost all Croatian media on his side and the public, who protested in 13 Croatian cities on 1 June 2016.

The hypothesis that Boris Jokić was the main source of information has been confirmed. Out of 349 articles, there were 164 articles where Predrag Šustar and Boris Jokić were information sources. Boris Jokić was the most used information source in 24 sata and Jutarnji list, equally in Večernji list ans Glas Slavonije, and the least in Slobodna Dalmacija. Predrag Šustar was the most used information source in Večernji list, followed by Jutarnji list, equally in Glas Slavonije and Novi list, and the least in Slobodna Dalmacija.

Table 12. Using main sources of information

\begin{tabular}{|l|c|c|c|c|c|c|}
\hline Source & $\begin{array}{c}24 \\
\text { sata }\end{array}$ & $\begin{array}{c}\text { Večernji } \\
\text { list }\end{array}$ & $\begin{array}{c}\text { Jutarnji } \\
\text { list }\end{array}$ & $\begin{array}{c}\text { Glas } \\
\text { Slavonije }\end{array}$ & $\begin{array}{c}\text { Novi } \\
\text { list }\end{array}$ & $\begin{array}{c}\text { Slobodna } \\
\text { Dalmacija }\end{array}$ \\
\hline Boris Jokić & 22 & 18 & 21 & 18 & 16 & 7 \\
\hline Predrag Šustar & 14 & 16 & 15 & 8 & 8 & 4 \\
\hline
\end{tabular}

\section{Conclusion}

This research was focused on analysing the articles in online editions of daily newspapers and the way the public was informed on education, curricular reform, and especially the meaning and place of media literacy in education. The results showed that there were many articles on the curricular reform in Croatian media, but they were not objective, especially due to the way the information sources were used in the reports, which was mostly superficial, and the headlines sensationalist. In conclusion, the media reports have not contributed to the understanding of the importance of the curricular reform, and they have not explained the role, significance and meaning of media literacy and the need to include it in the formal educational system. This conclusion is also drawn from the analysis of informational value and the quality of articles on media literacy, which was low. It should be pointed out that the main hypothesis on media not devoting enough attention to promoting media literacy in the Croatian education system has been confirmed, and especially at the time when they had an opportunity to do so, i.e. at the time of discussion on the implementation of the integrated curricular reform. 


\section{Reference List}

- Car, V., Kanižaj, I., Kralj, L. (2014/2017). Media and Information Literacy Policies in Croatia 2013. In: Frau-Meigs, D., Velez, I., Flores Michel, J. (Eds.), Public Policies in Media and Information in Europe: Cross-Country Comparisons. London: Routledge. Retrieved from: http://ppemi.ens-cachan.fr/data/media/colloque140528/rapports/CROATIA_2014.pdf. 10 November 2017.

- Car, V., Matović, M., Turčilo, L. (Eds.), (2016). Mediji i javni interes. Zagreb: Fakultet političkih znanosti Sveučilišta u Zagrebu - Hanns Seidel Stiftung.

- Ciboci, L., Osmančević, L. (2015). Kompetentnost nastavnika hrvatskoga jezika za provođenje medijske kulture u hrvatskim osnovnim školama. In: Car, V., Turčilo, L., Matović, M. (Eds.), Medijska pismenost - preduvjet za odgovorne medije (pp. 121138). Sarajevo: Fakultet političkih nauka Univerziteta u Sarajevo.

- Erjavec, K., Zgrabljić Rotar, N. (2000). Odgoj za medije u školama u svijetu: hrvatski model medijskoga odgoja. Medijska istraživanja, 6 (1), 89-107.

- Erjavec, K. (2005). Odgoj za medije: od koncepta do školske prakse. In: Zgrabljić Rotar, N. (Ed.), Medijska pismenost i civilno društvo (pp. 77-106). Sarajevo: Mediacentar.

- Kanižaj, I., Car, V. (2015). Hrvatska: Nove prilike za sustavan pristup medijskoj pismenosti. In: Car, V., Turčilo, L., Matović, M. (Eds.), Medijska pismenost - preduvjet za odgovorne medije (pp. 19-38). Sarajevo: Fakultet političkih nauka Univerziteta u Sarajevu.

- Kunczik, M. (2014). Masovni mediji i njihov utjecaj na društvo. In: Malović, S., Maletić, F., Vilović, G., Kurtić, N. (Eds.), Masovno komuniciranje (pp. 17-39). Zagreb: Golden marketing - Tehnička knjiga, Sveučilište Sjever.

- Labaš, D. (2015). “Djeca medija” - mladi obrazuju mlade. In: Car, V., Turčilo, L., Matović, M. (Eds.), Medijska pismenost preduvjet za odgovorne medije (pp. 109-121). Sarajevo: Fakultet političkih nauka Univerziteta u Sarajevu.

- Maletić, F. (2014). Medijska pismenost. In: Malović, S., Maletić, F., Vilović, G., Kurtić, N. (Eds.), Masovno komuniciranje (pp. 137-225). Zagreb: Golden marketing - Tehnička knjiga, Sveučilište Sjever.

- Malović, S. (2014). Masovno komuniciranje. In: Malović, S., Maletić, F., Vilović, G., Kurtić, N. (Eds.), Masovno komuniciranje (pp. 43-132). Zagreb: Golden marketing - Tehnička knjiga, Sveučilište Sjever.

- Zgrabljić Rotar, N. (2005). Mediji - medijska pismenost, medijski sadržaji i medijski utjecaji. In: Zgrabljić Rotar, N. (Ed.), Medijska pismenost i civilno društvo (pp. 9-43). Sarajevo: Mediacentar. 


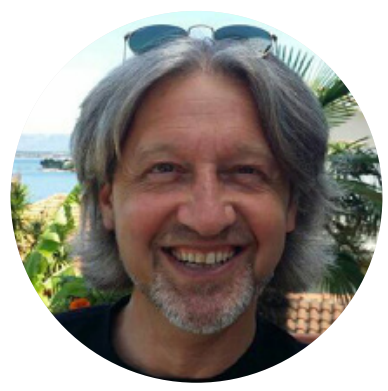

\section{Danijel Labaš}

Danijel Labaš is associate professor at the Department of Communication Studies of University Department of Croatian Studies at the University of Zagreb. He teaches several subjects in the field of communication studies and journalism, semiotics, media ethics, media pedagogy, religion and film. He is a visiting professor of postgraduate interdisciplinary university studies at Faculty of Humanities and Social Sciences in Zagreb, at the Doctoral School of the University of Josip Juraj Strossmayer in Osijek, at the University of Mostar and a specialist study in Public Relations at the Faculty of Political Science in Zagreb. He is president of the Association for Communication and Media Culture, and a member of the Croatian Commission for Cooperation with the United Nations Educational, Scientific and Cultural Organization (UNESCO), the Croatian Matrix (Matica hrvatska) and the Croatian Society of Catholic Journalists.

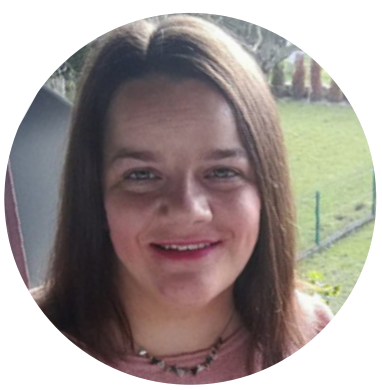

\section{Petra Marinčić}

Petra Marinčić is the editor-in-chief at Televizija Zapad. She has a masters degree in communication studies and history from the University Department for Croatian Studies at the University of Zagreb. After university she worked as an associate at a publishing house, and since December 2015 she has been at Televizija Zapad as chief editor. So far, she was in charge of editing on multiple genres of informative TV programmes: documentary (Gradski ekran), medical health (Otpusno pismo), educational (Veliki i mali), informative (Pravo kroz život and Iza zida). For the last two mentioned programmes she has been awarded with the 'Svjetionik' award for dignified reporting on poverty (December 2016) and the Annual award for journalist work which promotes workplace safety (April 2017). In the student days her efforts were awarded with the University director's award and Dean's award in 2011. 